\title{
Effect of high-intensity interval training on treadmill exercise with changes in inclination on serum hsCRP levels in overweight/obese men
}

\author{
I Komang Gede Dwi Maya Rustadia, Damayanti Tinduh ${ }^{\mathrm{a}}$, I Putu Alit \\ Pawana ${ }^{\mathrm{a}}$, Sony Wibisono \\ aDepartment of Physical Medicine and Rehabilitation, Faculty of Medicine Universitas Airlangga/ \\ Dr. Soetomo Academic General Hospital, Surabaya, Indonesia \\ Corresponding author: damayanti.tinduh@fk.unair.ac.id
}

\begin{abstract}
Background: Overweight and obesity have been associated with cardiovascular disease, diabetes mellitus type 2, osteoarthritis, respiratory disorders, cancer, and decline in life expectancy. Elevation in pro-inflammatory cytokine has been associated with decline in metabolic function and the rise in various diseases risk factors. C-reactive protein which is synthesized at the liver has been used to evaluate low-grade risk systemic inflammation. High-intensity Interval Training (HIIT) have been developed as an alternative exercise with low volume and expected to help efficiently reduce risk factors associated with the overweight condition.
\end{abstract}

Objective: To evaluate the effect of the HIIT exercise program for 4 weeks on hsCRP serum level in overweight men in Medical Rehabilitation Outpatient Clinic at dr. Soetomo Hospital.

Methods: This study was conducted from January-March 2021. Eighteen men visited Medical Rehabilitation Outpatient Clinic at dr. Soetomo Hospital recruited and randomized into the control and exercise groups. The exercise group performed the HIIT exercise program for 4 weeks while the control group received no intervention. Peripheral blood samples for serum hsCRP were collected at baseline and 30 minutes post training at the first and the last exercise in the exercise group.

Results: Within-group comparison in exercise and control group; and between group comparison of serum baseline hsCRP levels, showed no significant difference $(\mathrm{p}=0,176, \mathrm{p}=0,09$, and $\mathrm{p}=$ 0,04 , respectively). Within-group acute hsCRP levels showed no significant difference $(\mathrm{p}=0,163)$.

Conclusion: The HIIT exercise program for 4 weeks showed no significant effect on serum hsCRP levels in overweight men.

Keywords: high-intensity interval training (HIIT); overweight; obesity; hsCRP 


\section{Introduction}

One of the main health problems in the world is overweight and obesity. These conditions strongly associated with cardiovascular disease, diabetes mellitus type 2, osteoarthritis, respiratory disorders, and cancer. American College of Sports Medicine (ACSM) recommends moderate intensity aerobic exercise for at least 150 minutes per week (30 minutes each, 5 times a week) accompanied by 2-3 resistance training in a week. Lately, high-intensity Interval Training (HIIT) have been developed as an alternative method to help efficiently reduce risk factors associated with the overweight condition.

C-reactive protein is one of the inflammatory markers synthesized in the liver as a low-grade inflammatory response. High-sensitivity C-Reactive Protein (hsCRP) emerged as a remarkable examination due to its sensitivity in detecting slight alteration in low grade systemic inflammation. There is a substantial relationship between hsCRP and overweight where hsCRP levels are higher in people with overweight and obesity compared to people with normal BMI (Lavanya et al., 2017). CRP is an acute-phase reactant that is sensitive to systemic inflammation. CRP is a precursor to metabolic syndrome and type 2 diabetes, as well as a strong predictor reflecting the early phase of cardiovascular disease (Kawamoto et al., 2013). Adipose tissue (visceral fat) has a role in inducing low-grade inflammation in the liver. This process occurs through the synthesis of cytokines such as IL-6. The overweight condition associated with CRP concentrations and the close relationship between inflammation and overweight explains why the overweight group is more prone to cardiovascular disease. (Kawamoto, et al., 2013).

CRP levels increase momentarily up to 24 hours post-exercise. A systematic review study by Kasapis and Thompson found an increase in the acute phase response (APR) for up to 24 hours then returned to baseline 2 to 6 days after strenuous exercise. The mechanism underlying the postexercise increase in APR involves IL-1, IL-6, and TNF- $\alpha$. These cytokines increased transiently during and after exercise (except TNF- $\alpha$ ). IL-6 stimulates CRP synthesis in the liver after strenuous exercise. Research on hsCRP is still very minimal in Indonesia and only assesses basal hsCRP levels without assessing the acute response. The researchers wanted to examine the effects of HIIT exercise with changes in inclination on hsCRP levels in overweight and obese men at basal levels and acute responses.

\section{Methods}

This research was performed at Physical Medicine and Rehabilitation outpatient clinic Dr. Soetomo Academic General Hospital in October-November 2020. Eighteen overweight or obese men who met the study criteria were randomly assigned to the treatment group $(n=9)$ and the control group $(n=9)$. The exercise group perform HIIT using a treadmill with incline changes for 30 minutes (starting with warming up and ending with cooling down, 5 minutes each) 3 times a week for 4 weeks. The high intensity was calculated using the Karvonen formula with high intensity defined as HR rest $+80-90 \%$ HR Reserve and low intensity defined as HR Rest +30 $40 \%$ HR Reserve. The control group did not receive intervention and was educated to continue daily activity as usual. Measurement of hsCRP levels was carried out before the first exercise (basal) and 30 minutes after the first exercise (acute response). Then, after 4 weeks of treatment, hsCRP levels were examined before the last exercise (baseline) and 30 minutes after the last exercise (acute response). This research has obtained an ethical clearance certificate from the ethics committee of Dr. Soetomo Hospital Surabaya. All data were analyzed using SPSS version 26.

\section{Results}

A total of 18 research participants successfully fulfills the intervention, no side effects were reported. Comparison of characteristics between the two study groups was compared based on age, height, weight, and BMI. From BMI data. All study subjects had reported no comorbidities 
(ischemic heart disease, heart rhythm disturbances, restrictive or obstructive airway disease). Participant who uses pacemakers, use of beta-blocker drugs, or other antiarrhythmic drugs were excluded from the study subjects.

Table 1 The Demographic and Anthropometric Data.

\begin{tabular}{|l|c|c|c|}
\hline Variable & Exercise group $(\mathrm{n}=9)$ & Control group $(\mathrm{n}=9)$ & $\mathrm{p}$ value \\
\hline Age $($ Years $)$ & $30.4 \pm 2.6$ & $36 \pm 1.8$ & 0.407 \\
\hline Height $(\mathrm{cm})$ & $168.3 \pm 5.8$ & $167.11 \pm 6.97$ & 0.794 \\
\hline Weight $(\mathrm{kg})$ & $79.5 \pm 10.3$ & $76.2 \pm 11.57$ & 0.482 \\
\hline BMI $\left(\mathrm{kg} / \mathrm{m}^{2}\right)$ & $28 \pm 2.7$ & $27.15 \pm 2.83$ & 0.657 \\
\hline
\end{tabular}

Values are presented as mean \pm SD. BMI: body mass index

There was no significant difference in basal hsCRP levels before and after the intervention in the exercise group ( $\mathrm{p}=0.176)$ and control group $(\mathrm{p}=0.09)$. The same results were also obtained in the assessment of acute hsCRP levels.

Table 2 hsCRP value after 4 weeks of observation in the exercise and control groups

\begin{tabular}{|c|c|c|c|c|}
\hline \multirow{2}{*}{ Parameter } & \multicolumn{2}{|c|}{ Exercise Group } & \multicolumn{2}{c|}{ Control Group } \\
\cline { 2 - 5 } & Pre & Post & Pre & Post \\
\hline hsCRP baseline $(\mathrm{mg} / \mathrm{dL})$ & $0.18 \pm 0.08$ & $0.28 \pm 0.21$ & $0.19 \pm 0.09$ & $0.29 \pm 0.17$ \\
\hline
\end{tabular}

Values are presented as mean \pm SD. Significantly different from baseline if $\mathrm{P}<0.05$

There was no significant difference between acute hsCRP levels after the first exercise and after the last exercise $(\mathrm{p}=0.163)$. We also measured the difference between the difference (delta) in basal values and 30 minutes after the first exercise and the last exercise. After being compared, there was no significant difference $(\mathrm{p}=0.376)$.

Table 3 hsCRP value 30 minutes after exercise in the exercise group

\begin{tabular}{|c|c|c|c|c|}
\hline \multirow{2}{*}{ Parameter } & \multicolumn{2}{|c|}{$1^{\text {st }}$ Exercise } & \multicolumn{2}{c|}{$12^{\text {th }}$ exercise } \\
\cline { 2 - 5 } & Baseline & Post exercise & Baseline & Post exercise \\
\hline hsCRP $(\mathrm{mg} / \mathrm{dL})$ & $0.18 \pm 0.08$ & $0.18 \pm 0.08$ & $0.28 \pm 0.21$ & $0.22 \pm 0.12$ \\
\hline
\end{tabular}

Values are presented as mean \pm SD. Significantly different from baseline if $\mathrm{P}<0.05$

\section{Discussion}

The results of this study showed that there was no decrease in hs-CRP levels in the treatment group after 4 weeks of High-Intensity Interval Training. This result is different from Homaee et al (2014) which reported a significant decrease in hs-CRP levels between the group given endurance training, the group was given HIIT exercise, and the group not given exercise after a 12-week observation period. However, in the study of Homaee et al (2014) the three groups were also given dietary arrangements. The diet is regulated so that there was a reduction in calories per week in each group $(3500 \mathrm{kcal} /$ week for the diet-only group, $2500 \mathrm{kcal} /$ week for the endurance and HIIT training group) with a composition of $50-55 \%$ carbohydrates, $15-25 \%$ protein, $25-30 \%$ fat. Homaee et al (2014) argue that calorie restriction accompanied by an increase in energy requirements through exercise can reduce body weight and CRP levels. The results of our study are in line with research conducted by Allen et al (2017) who reported that there was no significant change in serum CRP and TNF- $\alpha$ levels after 9 weeks of HIIT exercise. In the research of Allen et al (2017), dietary restrictions were also not carried out such as the research of Homaee et al (2014). Our study is also in line with a systematic review study by Fedewa et al (2017) which states that in addition to exercise, the most significant factors in influencing the decrease in CRP are improvements in body mass index (BMI) and a decrease in body fat percentage. A meta-analysis study by Khalafi and Symonds (2020) showed that there was no difference in serum CRP levels between the HIIT group and the control group or the HIIT group with the moderate or low-intensity exercise group. The study also mentions that to get the effect of changing IL- 6 and CRP requires at least 3 weeks of regular exercise or more. The researcher believes that there was no 
decrease in basal serum hs-CRP levels after 4 weeks of HIIT exercise because we only provided an exercise program for 4 weeks and did not control the diet of the study subjects.

This study showed that there was no difference in acute hsCRP levels between the first 30 minutes after the first exercise and 30 minutes after the last HIIT exercise. The changes in basal hsCRP levels with 30 minutes post-exercise between the 1st exercise and the 12th exercise also did not show any significant change. Kaspar et al (2016) reported that there was no significant change in CRP levels 30 minutes and 2 days after the HIIT exercise intervention. In a systematic review study by Kasapis and Thompson (2005), changes in the acute phase response are related to activity, muscle injury, muscle mass involved during exercise, and the type of exercise. Strenuous physical exercise causes a transient increase in the level of the acute phase response shortly after exercise. However, in the systematic review, most of which involved studies conducted on athletes, only one study with 3 untrained subjects was included. A systematic review study by Cerqueira et al (2020) found that the increase in hs-CRP levels was highest after 24 hours of strenuous physical exercise. The study by Draganadis et al. (2013) showed an increase in CRP levels occurred 1-2 days after exercise before returning to baseline values. Marklund et al. (2013) reported an increase in CRP levels 30 minutes and 28 hours post-exercise, with the increase at 28 hours post-exercise being greater than 30 minutes post-exercise. Several studies mention an increase in the acute phase response after strenuous exercise (Kasapis and Thompson, 2005). This acute-phase response-enhancing effect was accompanied by an increase in interleukin-1 (IL-1) and creatinine kinase (CK), suggesting that an increased post-exercise inflammatory response is associated with a post-exercise muscle injury. Moreover, the increase in post-exercise CRP levels was proportional to the increase in exercise duration as well. The longer the exercise and the higher the muscle injury (increased CK), the higher the post-exercise CRP levels. This increase continued for up to 48 hours post-exercise and returned to basal values 2 to 6 days post-exercise (Kasapis and Thompson, 2005). Researchers believe that there is no change in hs-CRP levels 30 minutes post-exercise can be caused by the physical activity in this study was not heavy enough to cause acute changes in hsCRP. In addition, it can also be influenced by the time the sample was taken.

\section{Conclusion}

There was no decrease in basal serum hsCRP levels in overweight/obese men who received HIIT treadmill exercise with changes in inclination for 4 weeks. There was no decrease in acute response serum hsCRP levels in overweight/obese men receiving HIIT treadmill exercise with a change in inclination for 4 weeks. Further study with a larger sample group is needed to increase confidence in the effect of HIIT treadmill exercises on blood hsCRP level.

\section{Acknowledgements}

We thank the Indonesian Government through the Directorate General of Higher Education, which has provided financial assistance for this research through the PTUPT grant program. Additionally, we thank LPDP, Indonesia which has provided a scholarship for the researcher.

\section{References}

Abdullah, A., Peeters, A., de Courten, M., et al. 2010. The magnitude of association between overweight and obesity and the risk of diabetes: a meta-analysis of prospective cohort studies. Diabetes Res Clin Pract. 89(3):309-319.

Abrantes, A.M., Friedman, J.H., Brown, R.A., Strong, D.R., Desaulniers, J., Ing, E., Saritelli, J. and Riebe, D., 2012. Physical activity and neuropsychiatric symptoms of Parkinson disease. Journal of Geriatric Psychiatry and Neurology, 25(3), pp.138-145.

Acheson, K.J., Blondel-Lubrano, A., Oguey-Araymon, S., Beaumont, M., Emady-Azar, S., Ammon-Zufferey, C., Monnard, I., Pinaud, S., Nielsen-Moennoz, C. and Bovetto, L., 2011. Protein choices targeting thermogenesis and metabolism-. The American journal of clinical nutrition, 93(3), pp.525-534.

Ahmadizad, S., Avansar, A.S., Ebrahim, K., Avandi, M. and Ghasemikaram, M., 2015. The effects of short-term high-intensity interval training vs. moderate-intensity continuous training on 
plasma levels of nesfatin-1 and inflammatory markers. Hormone molecular biology and clinical investigation, 21(3), pp.165-173.

Allen, N.G., Higham, S.M., Mendham, A.E., Kastelein, T.E., Larsen, P.S. and Duffield, R., 2017. The effect of high-intensity aerobic interval training on markers of systemic inflammation in sedentary populations. European journal of applied physiology, 117(6), pp.1249-1256.

Caballero, B. 2007. "World Health Organisation. Controlling the global obesity epidemic". Johns Hopkins Bloomberg School of Public Health. vol 29:1-5

Carmienke, S., Freitag, M.H., Pischon, T., Schlattmann, P., Fankhaenel, T., Goebel, H. and Gensichen, J., 2013. General and abdominal obesity parameters and their combination in relation to mortality: a systematic review and meta-regression analysis. European journal of clinical nutrition, 67(6), pp.573-585.

Cassidy, S., Thoma, C., Houghton, D. 2016. High-Intensity Interval Training: a Review of Its Impact on Glucose Control and Cardiometabolic Health. Diabetologia. Vol. 16. 1-17

Cerqueira, É., Marinho, D.A., Neiva, H.P. and Lourenço, O., 2020. Inflammatory effects of high and moderate intensity exercise-A systematic review. Frontiers in physiology, 10, p.1550.

Chandrashekara, S., 2014. C-reactive protein: An inflammatory marker with specific role in physiology, pathology, and diagnosis. Internet Journal of Rheumatology and Clinical Immunology, 2(S1).

Champbell, WW. 2013. DeJong's The Neurologic Examination. Seventh Edition. Lippincott William \& Wilkins. Philadelphia, USA.

Cifu, David X. 2016. Braddom's Physical Medicine and Rehabilitation. Fifth Edition. Elsevier Health Sciences, Philadelphia.

Cuccurullo, S. 2004. Physical medicine and rehabilitation board view. USA. Demos.

De Luca, C. and Olefsky, J.M., 2008. Inflammation and insulin resistance. FEBS letters, 582(1), pp.97-105.

Fedewa, M.V., Hathaway, E.D. and Ward-Ritacco, C.L., 2017. Effect of exercise training on C reactive protein: a systematic review and meta-analysis of randomised and nonrandomised controlled trials. British journal of sports medicine, 51(8), pp.670-676.

Fischer, P., \& Hilfiker-Kleiner, D. 2008. Role of gp130-mediated signalling pathways in the heart and its impact on potential therapeutic aspects. British journal of pharmacology, 153(S1), S414-S427

Flegal, K.M., Kit, B.K., Orpana, H. and Graubard, B.I., 2013. Association of all-cause mortality with overweight and obesity using standard body mass index categories: a systematic review and meta-analysis. Jama, 309(1), pp.71-82.

Galgani, J., Ravussin, E. 2008. Energy metabolism, fuel selection and body weight regulation. Int. J. Obes. 32, S109-S119.

Gibala, M., Little, J. Macdonald, M., Hawley J. 2012. Physiological adaptations to low-volume, high-intensity interval training in health and disease. J Physiol. 1077-1084

Gregor, M.F. and Hotamisligil, G.S., 2011. Inflammatory mechanisms in obesity. Annual review of immunology, 29, pp.415-445.

Guh, D.P., Zhang, W., Bansback, N., Amarsi, Z., Birmingham, C.L. and Anis, A.H., 2009. The incidence of co-morbidities related to obesity and overweight: a systematic review and meta-analysis. BMC public health, 9(1), pp.1-20.

Guzman, E. D., Mccarthy, K., Siu, A., Stoller, J. 2010. Frequency and causes of combined obstruction and restriction identified in pulmonary function test in adults. Respiratory care. Vol 55. 
Heydari, M., Freund, J., Boutcher, S. H. 2012. The Effect of High-Intensity Intermittent Exercise on Body Composition of Overweight Young Males. Journal of Obesity.1-8

Hammonds, T. L., Gatright, E. C., Goldstein, C. M., Penn, M. S., Hughes, J. W. 2016. Effects of exercise on c-reactive protein in healthy patients and in patients with heart disease: $\mathrm{A}$ meta-analysis. Heart Lung. 45(3) 273-282.

Henstridge, D.C., Febbraio, M.A. dan Hargreaves, M., 2016. Heat shock proteins and exercise adaptations. Our knowledge thus far and the road still ahead. Journal of applied physiology, 120(6), pp.683-691.

Homaee, H. M., Moradi, L., Peeri, M., Azarbayjani, M.A. 2014. Effect of high intensity exercise training (HIIT) and endurance training on weight loss and C-reactive protein in obese men. International Journal of Biosciences. 4 (9): 190-196

Ito. S. 2019. High-Intensity Interval Training For Health Benefits and Care of Cardiac DiseasesThe Key To an Efficient Exercise Protocol. World Journal of Cardiology. Vol. 11. Pp: 171-188

Jayaprakash, P., Bhansali, A., Bhansali, S., Dutta, P., Anantharaman, R., Shanmugasundar, G., Ravikiran, M. 2011. Validation of bedside methods in evaluation of diabetic peripheral neuropathy. Indian J Med Res. 133: 645-649.

Kamath, D.Y., Xavier, D., Sigamani, A., Pais, P. 2015. High sensitivity C-reactive protein (hsCRP) \& cardiovascular disease: An Indian perspective. Indian J Med Res. 142 261268

Karstoft, K., Winding, K., Knudsen, S. 2012. The effects of free-living interval-walking training on glycemic control, body Composition, and physical fitness in tipe 2 diabetic patients: a randomized, controlled trial. Diabetes Care. Vol:36. 228-236.

Kasapis, C. and Thompson, P.D., 2005. The effects of physical activity on serum C-reactive protein and inflammatory markers: a systematic review. Journal of the american College of Cardiology, 45(10), pp.1563-1569.

Kawamoto, R., Kusunoki, T., Abe, M., Kohara, K., Miki, T. 2013. An association between body mass index and high-sensitivity C-reactive protein concentrations is influenced by age in community-dwelling persons. Annals of Clinical Biochemistry. 50(5) 457-464

Kementerian Kesehatan Republik Indonesia. Hasil Utama Riskesdas 2018. [internet] 2019 [dikunjungi 29 Oktober 2019]. tersedia dari: depkes.go.id/resources/download/infoterkini/materi_rakorpop_2018/Hasil\%20Riskesdas\%202018.pdf

Kilpatrick, M. Little, J., \& Jung M, E. 2014. High-Intensity Interval Training: A Review of Physiological and Psychological Responses. ACSM's Health and Fitness Journal. Vol 5. 10-6

Krause, M., Heck, T.G., Bittencourt, A., Scomazzon, S.P., Newsholme, P., Curi, R. and Homem de Bittencourt, P.I., 2015. The chaperone balance hypothesis: the importance of the extracellular to intracellular HSP70 ratio to inflammation-driven type 2 diabetes, the effect of exercise, and the implications for clinical management. Mediators of inflammation, 2015.

Landry, A., Docherty, P., Ouellette, S. and Cartier, L.J., 2017. Causes and outcomes of markedly elevated C-reactive protein levels. Canadian Family Physician, 63(6), pp.e316-e323.

Lavanya, K., Ramamoorthi, K., Acharya, R.V., Madhyastha, S.P. 2017. Association between Overweight, Obesity in Relation to Serum hs-CRP Levels in Adults 20-70 Years. Journal of Clinical Diagnostic and Research. 11(12): 32-35

Luo, X., Zuo, X., Zhou, Y., Zhang, B., Shi, Y., Liu, M., Wang, K., McMillian, D.R. and Xiao, X., 2008. Extracellular heat shock protein 70 inhibits tumour necrosis factor- $\alpha$ induced 
proinflammatory mediator production in fibroblast-like synoviocytes. Arthritis research \& therapy, 10(2), pp.1-11.

Manore, M.M. 2015. Rethinking energy balance: Facts you need to know about weight loss and management. ACSM's Health Fit. J. 19, 9-15.

Manore, M.M. 2015. Weight management for athletes and active individuals: A brief review. Sports Med. 45, 83-92.

Manore, M.M., Meyer, N.L., Thompson, J. 2009. Sport Nutrition for Health and Performance, 2nd ed.; Human Kinetics: Champaign, IL, USA. 25-108.

Marklund, P., Mattsson, C.M., Wåhlin-Larsson, B., Ponsot, E., Lindvall, B., Lindvall, L., Ekblom, B. and Kadi, F., 2013. Extensive inflammatory cell infiltration in human skeletal muscle in response to an ultraendurance exercise bout in experienced athletes. Journal of applied physiology.

McCormack, J.P., Allan, G.M. 2010. Measuring hsCRP-An Important Part of a Comprehensive Risk Profile or a Clinically Redundant Practice?. PLoS Medicine. 7(2)

McCrae, G., Payne, A., Zelt, J. 2012. Extremely low volume, whole-body aerobic resistance training improves aerobic fitness and muscular endurance in females. J Appl Physiol Nutr Metab. Vol. 37. 1124-1131

Mendham, A.E., Duffield, R., Marino, F. and Coutts, A.J., 2014. Small-sided games training reduces CRP, IL-6 and leptin in sedentary, middle-aged men. European journal of applied physiology, 114(11), pp.2289-2297.

Morici. G., Gruttad'Auria. C.I., Baiamonte. P., Mazzuca. E., Castrogiovanni, A., et al. 2016. Endurance training: is it bad for you?. Breathe. 12: 140-147.

Novita, E. dan Zuraidah, E., Pengenalan Peran dan Mekanisme Heat Shock Protein (HSP) dalam Sistem Imun dan Keganasan. Pratista Patologi. 5(1), 10-17

Ouerghi, N., Fradj, M.K.B., Bezrati, I., Khammassi, M., Feki, M., Kaabachi, N. and Bouassida, A., 2017. Effects of high-intensity interval training on body composition, aerobic and anaerobic performance and plasma lipids in overweight/obese and normal-weight young men. Biology of sport, 34(4), p.385.

Perhimpunan Dokter Spesialis Kardiovaskular Indonesia. 2013. Pedoman Tatalaksana Dislipidemia Edisi Ke-1. Jurnal Kardiologi Indonesia. 24-25

Pescatello, L. S., Ross, A., Deborah, R., Paul, D. T. 2014. ACSM's Guidelines for Exercise Testing and Prescription. Ninth Edition. American College of Sport Medicine. Philadelphia: Lippincott Williams \& Wilkins, pp.73-75; 150-190.

Pratanu, S. Noer S, Waspadji S, Rachman M, Lesmana L, Widodo D, Isbagio H et al. 2006. Elektrokardiografi. Buku Ajar Ilmu Penyakit Dalam . Jilid I, Edisi ketiga. Jakarta . Balai Penerbit FKUI.

Phillips, M. D., Patrizi, R. M., Cheek, D.J., Wooten, J. S., Barbee, J.J., Mitchell, J.B. 2012. Resistance training reduces subclinical inflammation in obese, postmenopausal women. Med Sci Sports Exerc. 44:2099-2110

Riebe D, Ehrman JK, Liguori G, Magal. 2018. ACSM's Guidelines for Exercise Testing and Prescription. Tenth Edition. Philadelphia: Wolters Kluwer, pp.227-236, 379-385.

Sabbah, N.A., Rezk, N.A. dan Saad, M.S., 2019. Relationship Between Heat Shock Protein Expression and Obesity With and Without Metabolic Syndrome. Genetic testing and molecular biomarkers, 23(10), pp.737-743.

Speiser, P.W., Rudolf, M. C. J., Anhalt, H., Comacho-Hubner, C., Chiarelli, F., Elakim, A, et al. 2005. Childhood obesity. Journal of Clinical Endocrinology \& Metabolism. 90:18711887. 
Springer, B., Marin, R., Cyhan, T., Roberts, H., Gill,. N. W. 2007. Normative Values for The Unipedal Stance Test with Eyes Open and Closed. Journal of Geriatric Physical Therapy. Vol. 30;1:07.

Sylta, Ø., Tønnessen, E., Hammarström, D., Danielsen, J., Skovereng, K., Ravn, T., Rønnestad, B., Sandbakk, Ø. and Seiler, S., 2016. The effect of different high-intensity periodization models on endurance adaptations.

Taylor, J. L., Holland, D. J., Spathis, J. G. 2019. Guidelines for the Delivery and Monitoring of High Intensity Interval Training in Clinical Populations, Progress in Cardiovascular Diseases. 62 (2): 140-146

Teixeira, B. C., Lopes, A. L., Macedo, R. C. O., Correa, C. S., Ramis, T. R., et al. 2014. Inflammatory markers, endothelial function and cardiovascular risk. J Vasc Bras. 13 (2): 108-115

Tjønna, A., Lee, S., Rognmo, Ø. 2008. Aerobic interval training versus continuous moderate exercise as a treatment for the metabolic syndrome: A pilot study. Circulation. Vol: 118. 346-354

Tolfrey, K., Smallcombe, J. 2017. Oxford Textbook of Children's Sport and Exercise Medicine, 3rd ed. Oxford. Oxford University Press. 477-91

Villereal, D. T., Miller, B. V, Banks, M., Fontana, L., Sinacore, D. R., Klein, S. 2006. Effect of lifestyle intervention on metabolic coronary heart disease risk factors in obese older adults. Am J Clin Nutr. 84(6): 1317-23

World Health Organization. 2000.Obesity: preventing and managing the global epidemic. World Health Organization. Technical Report Series 894, Geneva

World Cancer Research Fund/American Institute for Cancer Research. 2007. Food, Nutrition, Physical Activity, and the Prevention of Cancer: a Global Perspective. AICR, Washington DC

World Health Organization. 2013. Global action plan for the prevention and control of NCDs 2013-2020. World Health Organization, Geneva

World Health Organization. 2016. Obesity and overweight. WHO https://www.who.int/mediacentre/factsheets/ fs311/en/ (2016).

Yanovski, J. A. 2018. Obesity: Trends in underweight and obesity — scale of the problem. Nat. Rev. Endocrinol. 14, 5-6. 12 